\title{
The Discourse of Animal welfare: A Case Study of JAAN (Jakarta Animal Aid Network) in Handling the Traveling Dolphins Circus
}

\section{Tasya Amalia Fitri}

Department of Government, Sultan Ageng Tirtayasa University

Tasyaamalia.fitri2000@gmail.com

\section{Riswanda}

Faculty of Politics and Social Science, Sultan Ageng Tirtayasa University

riswanda@untirta.ac.id

\author{
E-ISSN 2721-0642 \\ Article Info \\ Recieved: \\ August 22021 \\ Revised: \\ October 52021 \\ Accepted: \\ December 52021 \\ Doi Number \\ https://doi.org/10.37950/ijd.v3i3.109
}

\begin{abstract}
Animal welfare discourse in Indonesia is rarely published on various media platforms so that public knowledge about Animal welfare is still very lacking. This study makes a case for. socioenvironmental justice pf all sentient being. The study argues for the interconnectedness of socioenvironmental issue with the conundrum of political aspects in, in terms of the welfare of dolphins. The study contributes to intellectual discourse on governance. Qualitative approach was chosen with respect to testing out 'equality utilitarianism ethics to use Peter Singer's phrase. The study indicates that the greater understanding of utilitarianism has motivated Jakarta Animal Aid Network concerning dolphins welfare, The understanding shapes awareness and public education. It then influences Indonesian government decision to stop the traveling dolphins circus that often raises socio-environmental issues especially for those who care about the rights of all sentient being.
\end{abstract}

Keywords : animal welfare, dolphins, equality, ethics, governance. 


\begin{abstract}
Abstrak
Wacana kesejahteraan hewan di Indonesia jarang dipublikasikan di berbagai platform media sehingga pengetahuan masyarakat tentang kesejahteraan hewan masih sangat kurang. Studi ini membuat kasus untuk. keadilan sosial-lingkungan pf semua makhluk hidup. Studi ini berpendapat untuk keterkaitan masalah sosial-lingkungan dengan tekateki aspek politik, dalam hal kesejahteraan lumba-lumba. Studi ini berkontribusi pada wacana intelektual tentang pemerintahan. Pendekatan kualitatif dipilih sehubungan dengan menguji 'etika utilitarianisme kesetaraan untuk menggunakan frasa Peter Singer. Studi ini menunjukkan bahwa pemahaman yang lebih besar tentang utilitarianisme telah memotivasi Jaringan Bantuan Satwa Jakarta tentang kesejahteraan lumba-lumba. Pemahaman tersebut membentuk kesadaran dan pendidikan publik. Hal ini kemudian mempengaruhi keputusan pemerintah Indonesia untuk menghentikan sirkus lumbalumba keliling yang kerap menimbulkan masalah sosial-lingkungan terutama bagi mereka yang peduli terhadap hak-hak seluruh makhluk hidup.
\end{abstract}

Kata Kunci : kesejahteraan hewan, lumba-lumba, kesetaraan, etika, pemerintahan.

\title{
Introduction
}

The discussion about Animal welfare seems to be a less interesting topic in Indonesia. The topic is rarely found in either printedor electronic news Animal welfare is defined generally in the law no. 95 year 2012 concerning Veterinary Public Health of which Animal welfare is described as physical or mental state of animals according to the natural behavior of the animals. The protection of animals from inappropriate treatment by humans (Government Regulation of the Republic of Indonesia, 2012).

The discussion of Animal welfare are divided in to three themes, namely Welfare Science which is intended to freedom in measuring the effects on animals in different situations and environments. Secondly,Welfare Ethics which talk about how humans should treat animals, that related to to third discussion on Welfare Law discussing how humans should treat animals (Agustina, 2017). Most discussion includes all types of animals that interact with humans or where human intervention has affected the lives of animals. The terms animals refers to the animals that do not live in the wild, but animals that are under conservation program, laboratories, farm animals and pets. Some of the descriptions above are also intended as messages that have morals and values to humans that should be able to improve the quality of life of the animals. Animal welfare theories have emerged since the 19th century in England and have become a very significant focus in the 21st century (Agustina, 2017).

The discussion on Animal welfare that is well known in the world today is where many animal abuse and animal exploitation cases found.

Dolphins are phenomenal animals and have amazing behavior patterns and abilities. This skill is widely known by the whole world so they can admit that this 
dolphins has the potential for intelligence and high ability. However, who would have thought that their abilities and brilliant behavior patterns sometimes make them a target for humans for profit. The life of dolphins in groups makes this something that needs to be considered if the dolphins are taken and separated from the group, but unfortunately the death of dolphins in the wild has not made humans aware.

Exploitation of natural resources is a result of human greed for exploring without using ethics or morals and sufficient knowledge. The exploitation is common in Indonesia because of a lack of knowledge on animals rights. Some non-government organisations have done campaign againts wild animals exploitation. including the exploitation of dolphinsgiven dolphins are currently under threat of being employed and tortured, knowingly or unknowingly by the "owner".

Catching and employing dolphins as above can cause dolphins to become stressed out which is born from fear, anxiety and frustration which will then affect the mental and physical state of the dolphins. The small pool and the use of chlorine and its transfer from area to area do not use water, but the dolphins are only placed on a tarp, making the dolphins tortured. In addition, doing a traveling dolphins circus has to entertain people by going up on stage and causing the dolphin's body to become blistered and injured. Things like this are a very real reality, conservation agencies only exploit dolphins without thinking about the welfare of dolphins to rest, breed and even live. Activists create movements and communities to come together and unite their values which have the same goal, to stop the exploitation and abuse of animals, including dolphins.

The emergence of these movements foster the value of animal lovers to defend the rights of animals in the form of organizations, JAAN (Jakarta Animal Aid Network) is one of them. Jakarta Animal Aid Network in its ideology says that the values they bring are things that are rarely cared for by society and the government. Therefore, the Jakarta Animal Aid Network has a great influence in various actions and programs to help animals get welfare in accordance with what nature has provided, especially in this study that what JAAN is talking about is protected wildlife, namely dolphins. The rise of traveling dolphins circus that are being carried out by conservation organizations has made the Jakarta Animal Aid Network focus its target on trying to deal with it.

The emergence of this action regarding the welfare of dolphins was created due to the lack of attention from the government. JAAN onceheld a meeting with the government to discuss the welfare of dolphins and the traveling dolphins circus. However, the government gives license to the traveling dolphins circus in 2013 and was extended again (Fanny et al., 2013) This paper discusses Animal welfare in Indonesia by analyzing the role of the Jakarta Animal Aid Network (JAAN) in handling and influencing the policy reform of the Ministry of Environment and Forestry to stop the traveling dolphins circus. 


\section{Theoretical Framework}

\section{Animal Rights and Animal welfare}

Animal Rights or Animal Rights are rights owned by animals or animals themselves, namely the right to live and prosper. Tom Regan argues that animals have rights just like humans, he also argues that they have the same moral status as humans based on rights. It relies on an inherent value that every living being has an inherent value and anything that has value is a being that we should respect. To show respect to such a creature we cannot use it simply as a means to our (Hargrove, 1992). With that, to realize the achievement of Animal Human Rights, there is something called Animal welfare, meaning that if the animal or animal is prosperous, then its human rights have been fulfilled. Saunders Comprehensive Veterinary Dictionary defines Animal welfare as avoiding the abuse and exploitation of animals by humans by maintaining appropriate standards of fulfillment, general feeding and care, disease prevention and treatment and guarantees freedom from abuse and unnecessary discomfort and pain (Bousfield \& Brown, 2010). Meanwhile, OIW (The World Animal Health Organization) says that Animal welfare is how an animal copes with the conditions in which the animal lives or its own environment. Animals that are in a good state of well-being are comfortable, healthy, well-nourished, safe and able to express their natural behavior and do not suffer from conditions such as pain, fear and hardship. Good Animal welfare requires disease prevention and animal care, proper shelter, nutritional management and humane handling and if farm animals are slaughtered humanely. Therefore Animal welfare will not be far from a situation where animals are protected, cared for and treated ethically or humanely.

\section{Equality Utilitarianism Ethics (Peter Singer)}

In this study, the author takes the concept of ethics or moral action towards the treatment and use of animals that cannot be separated from Animal welfare. In his book Singer develops Utilitarianism which according to him is that as long as living things have the capacity to feel pain and try everything for their survival, these living things have interests and deserve to be treated ethically (Singer, 2009). Singer in his theory of ethical or moral principles gives reason to believe that the basic principle of equality where the equality of all living things is the principle of equal consideration of interests, including equal treatment in the relationship between humans and animals based on the consideration that humans and animals have interests and rights to the same survival rate (Singer, 1999).

\section{Governance: Decision Making (Mondy, Sharplin, Flippo)}

Governance is very different from government because it focuses less on the state and its institutions but rather on practices, management, implementation and social activities (Gorgulho et al., 2015). Decision making is a very important component for the lives of individuals and organizations because decision making can affect the success or failure of an organization, including government institutions. With the concept of governance, 
decision making is one of the implementations of governance because decisions are currently in a process that will continuously evaluate to achieve certain goals that have expectations of an action guiding decision makers towards the appropriate line of thinking. to achieve the main goal. Quoted from Mondy, Sharplin and Flippo the decision-making process is divided into 4, namely (Sola, 2019):

1) Identify the problem or opportunity which is meant by the process that must be considered is to see the problems that arise and the factors that cause these problems so that they can help in finding solutions.

2) Develop alternatives which is meant by the process of considering various possible ways for problem solvers without forgetting the time limit for making and making decisions.

3) Evaluate alternatives which is meant by the process of providing an assessment of each alternative by considering the strengths and weaknesses of each alternative which must be oriented towards achieving the goals of the organization or institution.

4) Choose and implement the best alternative which is meant by the process that must be carried out by a decision maker or actor that will produce a satisfactory and appropriate decision.

5) Evaluate the decision which is meant by the final process in decision making accompanied by an objective assessment of how the decision can solve the problem.

\section{Methodology}

Qualitative approach is considered suitable to find out the role of JAAN in creating public awareness on Animal welfare. In particular, Dolphins, which in reality not many people try to research or elaborate on case studies on the welfare of Dolphins in Indonesia related to Dolphin demonstrations in various regions, have become an important issue for JAAN to take a significant role so that it can influence the government in making policies or regulations. purposive networkis used to determine key informants.

Interviews were conducted with JAAN and government officials, namely the Ministry of Environment, then this interview session focused on the Welfare of Dolphins, the traveling dolphins circus and policies regarding this issue. In the interview process, the researcher used online media, then conducted a question and answer process with informants regarding this matter and the interview was conducted in a structured manner by preparing a list of questions. 
Figure 1:

Framework of thinking

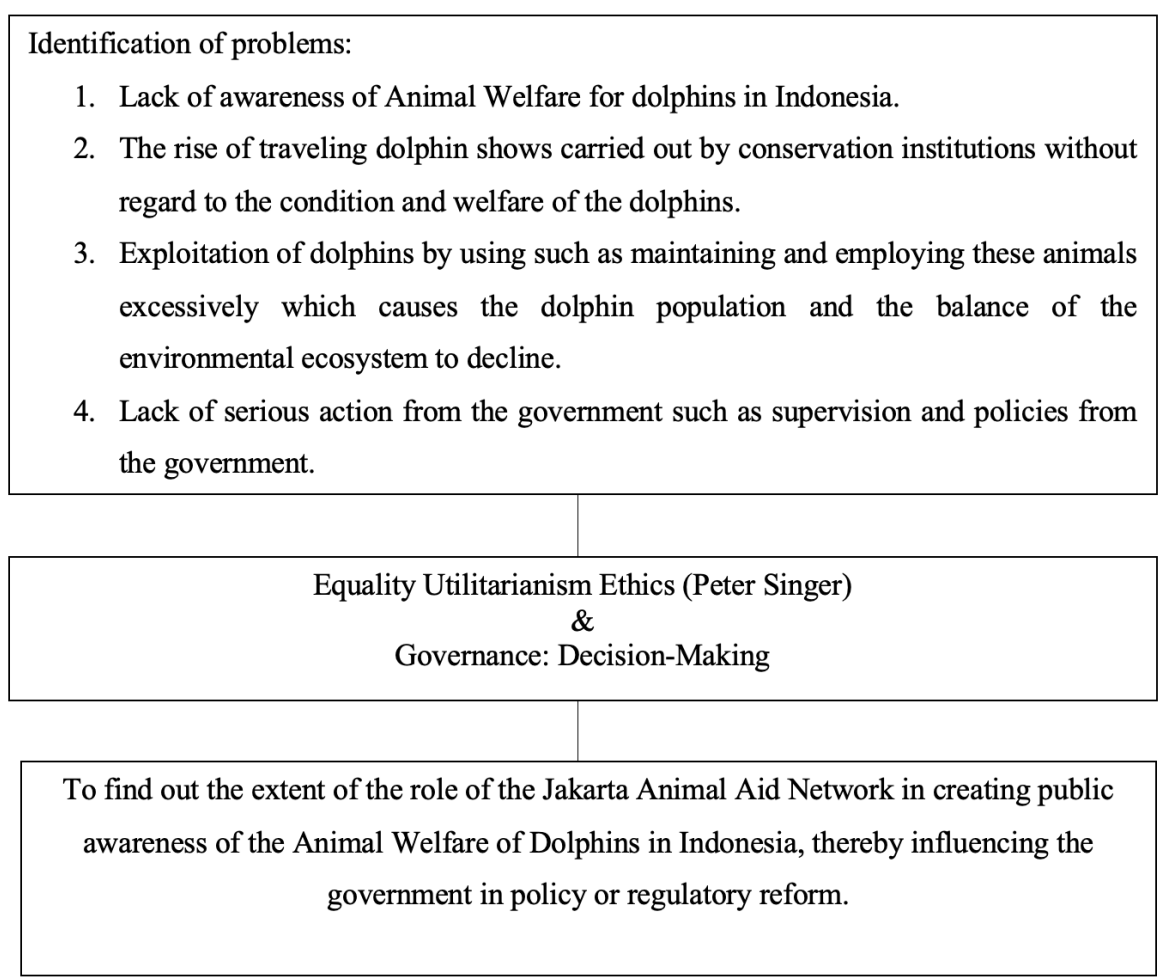

\section{Result and Discussion}

Dolphins are the most friendly wildlife in the world, apart from their intelligence. However, with the ability that dolphins have it can sometimes be a disaster for themselves, because humans can use it in a good way or vice versa. Dolphin showbusinessconducted by conservation organizations that have this license have developed into traveling dolphin circus. The circus is not only held in one place, but also moves around, sometimes the distance traveled is very far. As the reality explained above, that some of the conservation institutions only think about profit, while the welfare of the dolphins themselves are ignored. For example, as in the picture below which is the Instagram account of the JAAN campaign: 
Figure 2:

Evidence that the Traveling Dolphins Circus held does not meet the standards
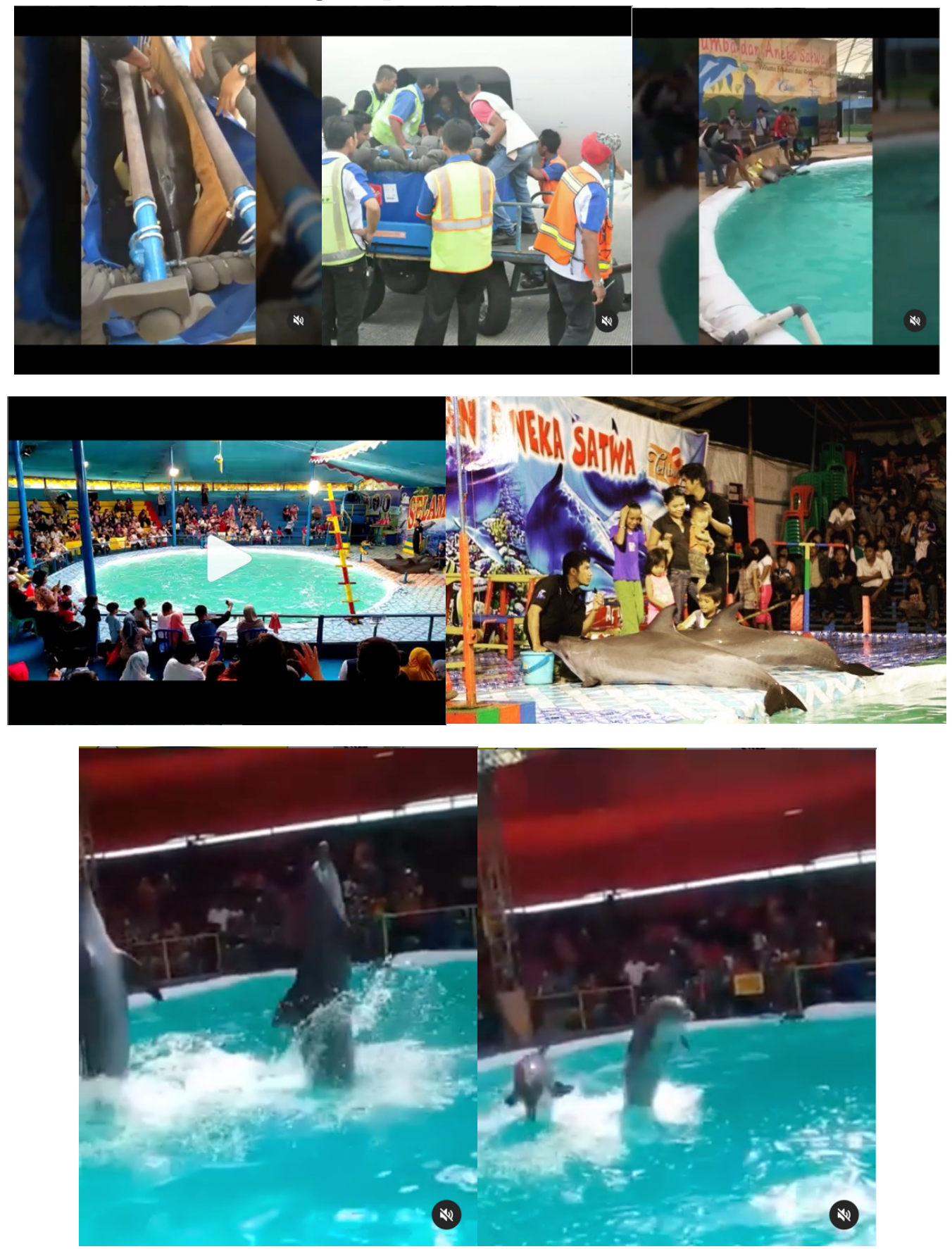

(Source: Instagram Campaign Stop Dolphins Circus Account)

Exploitation of natural resources is a result of human greed for exploring without using ethics or morals and sufficient knowledge, exploitation in Indonesia itself is commonplace because there is still a lack of knowledge and public awareness. It's not enough, now animal exploitation is on the rise, becoming a hot topic to be promoted by the Animal welfare movement and organization in Indonesia. Most of them use animals that have a lot of potential indiscriminately, therefore wild animals also become targets of exploitation for profit. Especially in this study, namely the exploitation of dolphins, as described above, exploitation of dolphins is a violation of Animal welfare because 
dolphins are currently being threatened with being employed and tortured, knowingly or unknowingly by the "owner".

In Indonesia, the dolphins circus is divided into two, namely the traveling circus and the circus in a fixed place. There are several corporations in Indonesia (Smarasanta, 2018):

1. PT. Jaya Ancol Tbk Development

2. PT. Taman Safari Indonesia CMD Tbk

3. PT. Wersut Segubi Indonesia (WSI)

4. Meika Animal Park

5. The Dolphin Lodge

Some of the corporations above are animal or animal conservation institutions including dolphins in them. The above institutions are conservation institutions that have official permits from the government in Indonesia. Conservation institutions according to the Regulation of the Minister of Forestry of the Republic of Indonesia No. P.31/MenhutII/ 2012 concerning Conservation Institutions are institutions that operate in the field of conservation of clay plants and animals outside their habitat (ex-situ), both government institutions and non-government institutions.

Catching and employing dolphins excessively as described above can cause dolphins to become stressed because of fear, anxiety and frustration which will then affect the mental and physical state of the dolphin. In the end, fatality occurred and caused the death of the dolphin. Dolphins do have intelligence and potential behavioral patterns but they are animals that are easily stressed. Robson divided the categories of dolphin deaths caused by mental and physical reactions (Carter, 1982):

a) Sudden death, when captured.

b) Death of dolphins that survived capture and pond transportation but died within a month of being caught.

c) Dolphins that died of respiratory problems after being held for a long time and suffered from pneumonia.

Dolphins can suffer shock in capture in addition to stress during travel in transportation and after landing which is then caged or placed in small pools and sometimes contains drugs such as chlorine in it.

Small pools and the use of chlorine and its transfer from area to area do not use water, but the dolphins are only placed on tarpaulins or wrapped in wet cloth or foam, sometimes the water content is already dry, making the dolphins tormented even though they can breathe with their lungs. In addition, performing a traveling dolphins circus must entertain people by going up on stage and causing the dolphin's body to become blistered and injured. Things like this are a very real reality, conservation agencies only exploit dolphins without thinking about the welfare of dolphins to rest, breed and even live. In the early 2000s, some thought that the actions described above were a form of exploitation and abuse of animals. Activists have made action from communities or animal-loving organizations to gather and unite their values that have the same goal, 
namely to stop the exploitation and abuse of animals, including dolphins, for example the JAAN organization (Jakarta Animal Aid Network).

Jakarta Animal Aid Network is a Non-Government Organization where this organization is a stand-alone organization formed by individuals or groups of people who move independently. JAAN was formed in February 2008 by Femke den Haas, Karin Franken and Natalie Stewart because at that time there were no non-governmental organizations that fought for the welfare of animals or various animals (Animal welfare) in Indonesia. JAAN only operates with donations from individuals and does not receive any financial support from the government. JAAN in carrying out its activities to improve Animal welfare in Indonesia is divided into two parts, namely the domestic and wildlife sections, the domestic section includes everything they do to help pets such as dog and cat adoption, dog meat-free Indonesia campaign, cat sterilization drive and emergency rescue. The wildlife rescue section covers all the cases they handle regarding primates, dolphins, tigers, orangutans and many more.

On its official website, JAAN mentions the ideology or values of what their organization stands for as follows (JAAN, 2021):

"Thousands of animals in Indonesia live miserable lives, they are often chained, locked up, neglected and even tortured. JAAN is a non-profit organization that seeks to reduce their suffering and provide them with a better life. We believe that no animal deserves cruelty and that no wild animal spends its life in captivity. JAAN focuses on raising awareness about animal suffering and promoting compassionate treatment for all the diverse animals in Indonesia (Animal welfare)."

This research focuses on the JAAN movement in Animal welfare for dolphins and the traveling dolphins circus government policies. Like the evidence that has been described above regarding the traveling dolphins circus which the Conservation Institute can torture some dolphins physically and mentally.

Jakarta Animal Aid Network in carrying out its activities as a non-governmental organization for animal lovers by carrying out its ideology which tries to raise values and mobilize the public in improving animal welfare (Animal welfare) in Indonesia, especially in this research dolphins. Benvika, leader of JAAN said that what moved them in the Animal welfare dolphins circus and the stoppage of the traveling dolphins circus was that dolphins in Indonesia were found to be unwell and were objected to in a traveling dolphins circus where they had to live in very large pools. small for many years while the dolphins themselves are very intelligent social living creatures and they live in the ocean without any restrictions, they have the right to survive the same as other living things compared to having to be caught and then trained just for the satisfaction and satisfaction of humans.

With the ideology of JAAN itself, it is driven by the utilitarianism of equality which has been described by Singer in which JAAN has ethical and moral principles where the equality of all living things has the same interests as getting the same treatment in the relationship between humans and animals which as Living things both have the same interests and rights to survive. With that, JAAN has a very significant role in the 
Animal welfare of dolphins and the stoppage of the traveling dolphins circus, the first thing JAAN did was lobby the government, hold a joint discussion about the itinerant dolphins circus which had to be stopped because there were so many unhappy dolphins found. In addition, JAAN also created a Stop Dolphins Circus campaign as a form of protest to stop the traveling dolphins circus activity and also as a form of education to the public that do not treat dolphins without thinking about their welfare and do not watch the traveling dolphin circuses around because it is reversed from entertainment. there is suffering experienced by the dolphins themselves.

Furthermore, they provided a solution to be ready to accommodate all the dolphins that were used as the object of the itinerant the traveling dolphins circus conducted by the conservation agency. After their capture, they collaborated with the Karimun Jawa National Park Agency to build a place for the dolphins to be rehabilitated. JAAN also signed an MoU (Memorandum Of Understanding) with the Ministry of Environment and Forestry of the Republic of Indonesia with the Directorate General of Natural Resources and Ecosystem Conservation and stated that they were ready to accept dolphins from the traveling circus as long as the traveling dolphins circus activity was dismissed. So that in September 2019, a decree was issued to stop and prohibit dolphin shows outside the Conservation Society or traveling dolphins circus. The policy issued is the Regulation of the Circular Demonstration of Protected Animal Species of Dolphins No.041/HUMAS/PP/HMS.3/02/2020 which contains (Hadi, 2020):

"Jakarta, the Ministry of Environment and Forestry, Thursday, February 6, 2020. The Ministry of Environment and Forestry together with the Conservation Agency, the holder of the permit for the circumnavigation of protected dolphins, agreed that the dolphins circus activities outside the Conservation Institution's environment should be stopped. This agreement was signed on July 21 2018, but because there are still Conservation Institutions whose licenses have not expired, namely PT. Ancol Dreamland Park and PT. Wersut Seguni Indonesia, the policy of stopping the traveling dolphins circus ends on February 5, 2020."

With encouragement from JAAN through lobbying, campaigns and solutions, the government finally accepted it and conducted a deeper discussion regarding the case of traveling dolphins circus in Indonesia. The response from the Ministry of Environment and Forestry regarding the activities carried out by JAAN is a form of aspiration that must be accepted by the government in order to reach consensus or mutual agreement with the same goal and benefit each other. Therefore, the Ministry of Environment and Forestry carries out the concept of decision making in order to implement governance related to the proposal from JAAN and the response to the case of traveling dolphins circus in Indonesia. Decision making carried out by the Ministry of Environment and Forestry is divided into 4 processes that refer to the theory of Mondy, Sharplin and Flippo, including (Sola, 2019):

1) Identify the problem or opportunity as evidenced by the Ministry of Environment and Forestry which states that after receiving input from JAAN regarding the Animal welfare of dolphins and the traveling dolphins circus, they conduct an 
assessment or identify problems or deeper cases before taking action. Furthermore.

2) Develop alternatives as evidenced by the Ministry of Environment and Forestry which states that after identifying the problem or case of the traveling dolphins circus proposed by JAAN, they make several solutions and then consider various ways to solve the problem within the specified timeframe to make a decision. .

3) Evaluate alternatives as evidenced by the Ministry of Environment and Forestry which states that after making various ways or solutions to solve problems, they evaluate these various ways by providing an assessment by considering the strengths and weaknesses of each alternative way of solving problems that must refer to to the achievement of organizational or institutional goals.

4) Choose and implement the best alternative as evidenced by the Ministry of Environment and Forestry which states that after considering the strengths and weaknesses of the alternative solutions they made, they choose and implement the right solution and produce appropriate and satisfactory decisions and ultimately become a policy was issued, namely the Regulation of the Circular Demonstration of Protected Animal Species of Dolphins No.041/HUMAS/PP/HMS.3/02/2020.

5) Evaluate the decision as evidenced by the Ministry of Environment and Forestry which states that after the decision or policy regarding the termination of the traveling dolphins circus carried out by the Conservation Institution is carried out, the Ministry of Environment and Forestry will continue to monitor, supervise and provide an assessment to measure the impact of the decision can solve the problem.

\section{Figure 3:}

Mapping on Animal welfare Issues

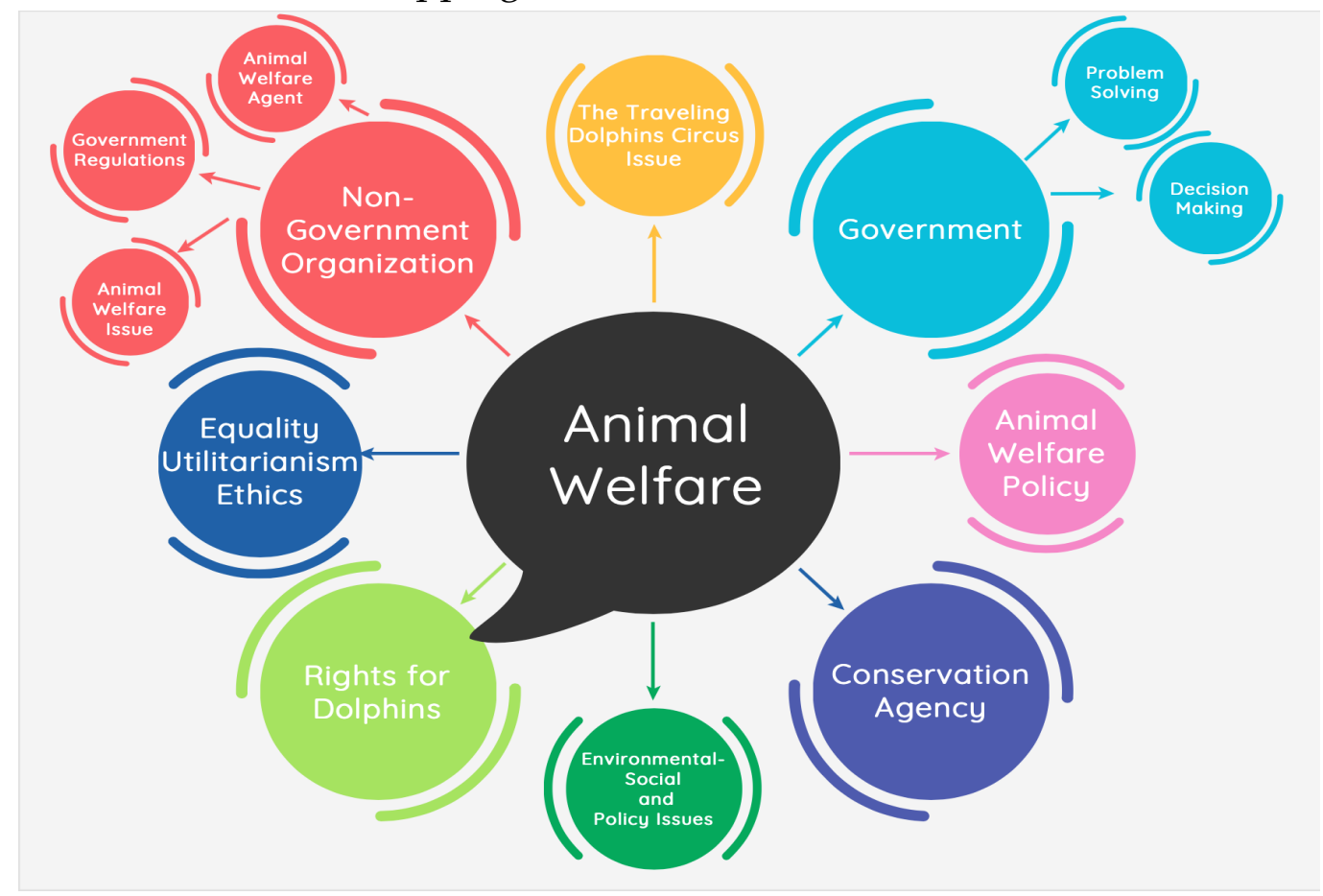


With that, JAAN in its role was successful in influencing the government (KLHK) to handle the case of the traveling dolphins circus. In the results of the research that has been studied and described above, it can be analyzed that from the point of view of the government or the Ministry of the Environment they are of the view that the traveling dolphins circus have been regulated in regulations, including guidelines for the process of carrying out demonstration activities or performances such as transportation and swimming. performances, transportation, management and ethics of Animal welfare carried out by licensed Conservation Institutions. With this regulation, they supervise all licensed Conservation Institutions that carry out traveling dolphins circus. Looking from the point of view of a non-governmental organization, the Jakarta Animal Aid Network is of the view that the traveling dolphins circus is an activity that is found not to be prosperous for the dolphins because it is only used as an object in the traveling dolphins circus where they have to live in a very small pool for many years while the dolphins themselves are very intelligent social living creatures and they live in the ocean without any restrictions, they have the right to survive the same as other living things compared to having to be caught and then trained just for the satisfaction and satisfaction of humans.

From these two perspectives, the reality and the problems found are that although the government has provided regulations regarding the guidelines for traveling dolphins circus, there is still much evidence found such as pictures sourced from the Stop Circus Dolphins social media account formed by JAAN above which violates the guidelines of the traveling dolphins circus without any regard or even concern for the welfare of the dolphins themselves. Meanwhile, with the regulations that have been made previously by the Ministry of Environment and Forestry and also if knowledge of Animal welfare awareness in Indonesia was high, this problem would not have occurred. Therefore, with the Animal welfare value, JAAN has taken action to stop the traveling dolphins circus and help the government and the public to see the reality that was happening and then cooperate so that finally the government updated the policy by stopping the traveling dolphins circus to re-enforce the regulations and also improve Animal welfare in Indonesia.

Table 1:

Contemporary issues in viewing diversity

\begin{tabular}{|c|c|c|c|}
\multicolumn{1}{c}{} & \multicolumn{2}{c|}{ Ability to Explain } \\
\cline { 2 - 4 } \multicolumn{1}{c|}{} & Facts & Values \\
\hline \multirow{2}{c|}{ Facts } & JAAN lenses & Government lenses \\
\hline & & & \\
\hline & Values & Government lenses & JAAN lenses \\
\hline & & & \\
\hline
\end{tabular}


According to contemporary issues in seeing diversity (Riswanda, 2021) and adapting from previous research (Widianingsih et al., 2020) the ability to explain is according to whose lens and what view dominates. How different lenses lead to different perceptions of Animal welfare, what kind of policy intervention is needed, depends on how and why policy makers and organizations have a common ground about what could be the root cause of a policy. Regulations regarding animal welfare are how they should be treated ethically and both humans and animals must live with respect for each other to complement each other's ecosystems. The governance approach can be a core value in making appropriate Animal welfare policy decisions. Research-based policy making must take into account the broad perspective that comes from the lens of the organization and the lens of government.

JAAN takes a significant role in inter-agency communication and the ability to run creative programs. Implementing animal welfare cannot stand alone, working together with the government will open up opportunities to solve problems related to dolphin welfare in the case of traveling dolphin shows. The level of awareness and knowledge affects Animal welfare and then in the long term explains what, how and why the public perceives this issue. The multi-layered aspects seem to lead to different ways of communicating dolphin Animal welfare issues, in turn, creating a relationship that is beneficial for both actors. JAAN's success in embracing the government to continuously increase the value of Animal welfare in Indonesia reflects the characteristics of organizations and governments that are innovative, able to seize opportunities, dare to take risks and carry out agreements to achieve common interests to raise awareness and educate the public in increasing the value of Animal welfare in Indonesia.

\section{Conclusion}

From the results of the research and discussion that have been reviewed and then described above, it can be concluded that the Ethical Utilitarianism of equality made JAAN (Jakarta Animal Aid Network) moved to intervene in handling the Animal welfare of dolphins and dolphin shows in Indonesia. JAAN's efforts and roles can be summed up as follows:

1. JAAN lobbied the government and held a joint discussion about the traveling dolphin show which had to be stopped because it was found that many of the dolphins were not prosperous.

2. JAAN made the Stop Dolphin Circus campaign as a form of protest to stop the traveling dolphin show activity and also as a form of education to the public that do not treat dolphins without thinking about their welfare and do not watch dolphin shows around because it is behind the entertainment there is suffering experienced by the dolphins themselves.

3. JAAN provides a solution to be ready to accommodate all dolphins that are used as the object of a dolphin show that is carried out by conservation agencies after their capture, they work together with the Karimun Jawa National Park Center to build a place for dolphin rehabilitation. 
4. JAAN also entered into an MoU (Momerandum Of Understanding) or what is often called a memorandum of understanding with the Ministry of Environment and Forestry of the Republic of Indonesia with the Directorate General of Natural Resources and Ecosystem Conservation and stated that they were ready to accept the dolphins resulting from the traveling show as long as the performance activities the traveling dolphin was dismissed.

The important role played by JAAN has paid off so that around 2018-2019 in September, a decree was issued by the Ministry of Environment and Forestry (KLHK) regarding the termination and prohibition of dolphin shows outside the LK or traveling dolphin shows conducted by the Ministry of Environment and Forestry. Then officially running on February 5, 2020, the form of policy issued is the Regulation of the Circular Demonstration of Protected Animal Species of Dolphins No.041/HUMAS/PP/HMS.3/02/2020.

\section{About Authors}

Tasya Amalia Fitri, is from Sultan Ageng Tirtayasa University majoring in Government Science, Faculty of Social and Political Sciences in 2017.

Riswanda, is an Associate Professor in Faculty of Politics and Social Science at Universitas Sultan Ageng Tirtayasa.

\section{Acknowledgements}

This study is part of final research project for undergraduate degree of governance, Department of Governance, Faculty of Politics and Social Science Universitas Sultan Ageng Tirtayasa. The researcher would like to thank all the discussions and reviews and support this research deserves to be published.

\section{References}

Agustina, K. K. (2017). Kesejahteraan Hewan “ Animal Welfare ." Kesejahteraan Hewan "Animal Welfare" Keseja, 1-53.

Bousfield, B., \& Brown, R. (2010). Animal Welfare. Veterinary Bulletin - Agriculture, Fisheries and Conservation Departement Newsletter, 1(4), 1-12.

Carter, N. (1982). Effects of psycho-physiological stress on captive dolphins. Int J Stud Anim Prob, 3(3), 193-198.

Fanny, V., Redi, A., Dari, D., Penempatan, T., \& Atraksi, D. A. N. (2013). Perlindungan Lumba-Lumba Sebagai Satwa Langka Yang Dilindungi Dari Tindakan Penempatan Dan Atraksi Hiburan Yang Tidak Sesuai. 1-26.

Gorgulho, J., Tavares, J., Páscoa, C., \& Tribolet, J. (2015). Governance: Decision-making Model and Cycle. Procedia Computer Science, 64, 578-585.

https:// doi.org/10.1016/j.procs.2015.08.569

Government Regulation of the Republic of Indonesia. (2012). Number 95 Year of 2012. Veterinary Public Health and Animal Welfare. 
Hadi, D. W. (2020). Pengaturan Peragaan Keliling Satwa Dilindungi Jenis Lumba-Lumba. Pejabat Pengelola Informasi Dan Dokumentasi KLHK.

Hargrove, E. C. (1992). The Animal Rights/Environmental Ethics Debate: The Environmental Perspective. State University of New York Press.

https:// books.google.co.id/books?id=8G4iDy1a0FcC\&pg=PR25\&lpg=PR25\&dq=R egan, + T.+and + P.+Singer, + eds.+Animal+Rights+and+Human+Obligations.+(Engle wood+Cliffs,+NJ:+Prentice+Hall,+1989)\&source=bl\&ots=3EDY17JNGm\&sig=ACf U3U0RMYP91p2PmZcENCM5mKKuJwOrLQ\&hl=en\&sa=X\&

JAAN. (2021). About Jakarta Animal Aid Network.

Riswanda. (2021). The Emerging Trends and Issues in Contemporary Social and Public Policy: 'Systemic thinking and practice', Contemporary Issues and Trends in Social Sicences, in the Era of Internet of Things. UIN Bandung.

Singer, P. (1999). Practical Ethics 2nd edition.

Singer, P. (2009). Animal Liberation: The Definitive Classic of the Animal Movement.

Smarasanta, B. M. (2018). Penegakan Hukum Terhadap Satwa yang Dilindungi dalam Tidak Pidana Memelihara Lumba-Lumba Untuk Pertunjukan Dihubungkan Dengan Asas Kepastian Hukum. Universitas Pasundan.

Sola, E. (2019). DECISION MAKING: Sebuah Telaah Awal. Idaarah: Jurnal Manajemen Pendidikan, 2(2), 208. https:/ / doi.org/10.24252/idaarah.v2i2.7004

Widianingsih, I., Riswanda, R., \& Paskarina, C. (2020). Governing Water, Engaging Community: Indonesian Water Security Roadmap. Journal of Governance, 5(2). https:/ / doi.org/10.31506/jog.v5i2.9301 